\title{
Petrotoga mobilis sp. nov., from a North Sea oil-production well
}

\author{
Torleiv Lien, ${ }^{1}$ Marit Madsen, ${ }^{1}$ Fred A. Rainey ${ }^{\dagger} \dagger$ and Nils-Kåre Birkeland ${ }^{1}$
}

\author{
Author for correspondence: Torleiv Lien. Tel: +4755582669 . Fax : +4755589671. \\ e-mail: torleiv.lien@im.uib.no
}

\footnotetext{
1 Department of

Microbiology, University of

Bergen, IM, Jahnebakken

5, N-5020 Bergen, Norway

2 DSMZ, Mascheroder Weg 1b, D-38124 Braunschweig, Germany
}

\begin{abstract}
Rod-shaped, thermophilic bacteria with a sheath-like outer structure ('toga') were isolated from hot oilfield water of a North Sea oil reservoir. One of the isolates, designated SJ95', is an obligately anaerobic, sheathed, Gramnegative, fermentative bacterium capable of reducing elemental sulfur to hydrogen sulfide and tolerating high salt concentrations. The optimum growth conditions for this isolate are $58-60{ }^{\circ} \mathrm{C}$ and pH $6.5-7-0$ with $3-4 \% \mathrm{NaCl}$ and $0.7 \%$ $\mathrm{MgSO}_{4} .7 \mathrm{H}_{2} \mathrm{O}$ in the medium. Vitamins are required for growth. Growth is stimulated by yeast extract. Cells of strain SJ95' vary in size from 1-2 to 40-50 $\mu \mathrm{m}$ in length and are motile with a subpolar flagellation. Cells grown on xylan have xylanase activity, presumably associated with the toga, and glucose isomerase activity was detected in xylose-grown cells. The DNA G+C content is 31 and $34 \mathrm{~mol} \%$, determined by the thermal denaturation and HPLC methods, respectively. Phylogenetically, strain $\mathrm{SJ}^{\mathrm{T}}{ }^{\mathrm{T}}$ is most closely related to Petrotoga miotherma with a $97.7 \%$ similarity level between their 165 rDNA sequences. The DNA-DNA reassociation value between the two DNAs was $35.6 \%$. On the basis of differences in genotypic, phenotypic and immunological characteristics, strain SJ95' (= DSM 10674') is proposed as the type strain of a new species, Petrotoga mobilis. It can be readily distinguished from $P$. miotherma by its motility.
\end{abstract}

Keywords: Petrotoga mobilis sp. nov., thermophile, oilfield water

\section{INTRODUCTION}

In recent years, several new members of the order Thermotogales have been isolated from volcanically and non-volcanically heated geothermal environments (Andrews \& Patel, 1996; Fardeau et al., 1997; Jeanthon et al., 1995; Koch et al., 1997). Thermotogales currently comprises five genera, Thermotoga (Huber et al., 1986), Thermosipho (Huber et al., 1989), Fervidobacterium (Huber et al., 1990), Geotoga and Petrotoga (Davey et al., 1993). All members of the Thermotogales group have a characteristic outer sheath-like structure ('toga'); they are thermophilic and hyperthermophilic prokaryotes representing an early divergence within the (eu)bacterial line of descent (Winker \& Woese, 1991).

\footnotetext{
†Present address: Department of Biological Sciences, 508 Life Sciences Building, Louisiana State University, Baton Rouge, LA 70803, USA.

The EMBL accession number for the 16S rDNA sequence of strain SJ95 ${ }^{\top}$ reported in this paper is $\mathrm{Y} 15479$.
}

The North Sea oil reservoirs constitute a hot subterranean biosphere $1 \cdot 2-6.0 \mathrm{~km}$ below the sea floor. Environmental parameters (temperature, pressure, $\mathrm{pH}$, salinity, concentration of heavy metals, petroleum composition) vary widely from reservoir to reservoir. For instance, the temperature is $60-200{ }^{\circ} \mathrm{C}$ with an increase of $1{ }^{\circ} \mathrm{C}$ per $24-30 \mathrm{~m}$ increase in depth and the in situ pressure is $150-800$ bar (15-80 MPa). Various physiological types of thermophilic prokaryotes have been isolated from petroleum reservoirs, e.g. sulfidogens (Beeder et al., 1994, 1995; Nilsen et al., 1996; Rees et al., 1995; Rosnes et al., 1991a), methanogens (Nilsen \& Torsvik, 1996), and Thermotogales genera (Andrews \& Patel, 1996; Davey et al., 1993; Fardeau et al., 1997; Jeanthon et al., 1995; Stetter et al., 1993).

The only Petrotoga sp. described so far is Petrotoga miotherma, which was isolated from petroleum reservoirs in Oklahoma and Texas, USA (Davey et al., 1993). It is moderately thermophilic with an optimum growth temperature of $55^{\circ} \mathrm{C}$, non-motile, rod-shaped with a toga, obligately anaerobic, fermentative and 
capable of reducing elemental sulfur to hydrogen sulfide. Petrotoga differs from the other Thermotogales genera by its higher salt tolerance and 16S rRNA sequence, which shows it to be a distinct lineage within this order.

Organisms with a sheath-like outer structure have been isolated from North Sea oil wells. In this paper, the general characteristics and phylogenetic position of one of the isolates, strain SJ95 $5^{\mathrm{T}}$, are described. Although it is phylogenetically closely related to $P$. miotherma, strain SJ95 $5^{\mathrm{T}}$ differs in terms of its genotypic, phenotypic and immunological properties. Therefore, strain $\mathrm{SJ} 95^{\mathrm{T}}$ is proposed as a new species, Petrotoga mobilis sp. nov.

\section{METHODS}

Organisms and source of inoculum. Strain $\mathrm{SJ} 95^{\mathrm{T}}$ was enriched from anoxic samples of production water taken from the water separator tanks on off-shore oil platforms. The pressure in the separators was 1-80 bar $(0 \cdot 1-8 \mathrm{MPa})$, the temperature was $70^{\circ} \mathrm{C}$ and the $\mathrm{pH}$ was 7.8 , measured after pressure release. $P$. miotherma (ATCC $51224^{\mathrm{T}}$ ) was obtained from the American Type Culture Collection (Rockville, MD, USA).

Enrichment, isolation and cultivation. Enrichment and routine cultivation were done in a medium containing the following components $\left(1^{-1}\right): \mathrm{NaCl}, 30 \cdot 0 \mathrm{~g} ; \mathrm{MgSO}_{4} \cdot 7 \mathrm{H}_{2} \mathrm{O}$, $7.0 \mathrm{~g} ; \mathrm{KCl}, 0.34 \mathrm{~g} ; \mathrm{NH}_{4} \mathrm{Cl}, 0.25 \mathrm{~g} ; \mathrm{CaCl}_{2} .2 \mathrm{H}_{2} \mathrm{O}, 0.14 \mathrm{~g}$; $\mathrm{KH}_{2} \mathrm{PO}_{4}, 0.14 \mathrm{~g}$; yeast extract (Difco), $0.2 \mathrm{~g} ; 1 \mathrm{ml}$ trace element solution SL-10 (Widdel et al., 1983); and $0.5 \mathrm{ml}$ resazurin $(0.02 \%)$. After autoclaving in a dispenser (Lien \& Beeder, 1997), the hot medium was reduced with $4 \mathrm{ml} 0.5 \mathrm{M}$ $\mathrm{Na}_{2} \mathrm{~S} .9 \mathrm{H}_{2} \mathrm{O}$ under argon gas. The $\mathrm{pH}$ was adjusted to 6.5 with $6 \mathrm{M} \mathrm{HCl}$ and $10 \mathrm{ml}$ vitamin solution (Balch et al., 1979) was added. The medium was dispensed into 50 or $200 \mathrm{ml}$ serum bottles and Bellco tubes no. 2047 (Vineland) sealed with butyl rubber stoppers and aluminium crimp seals and a gas phase of argon $(200 \mathrm{kPa})$. Before inoculation with $10 \%$ inoculum, the substrates were added separately by syringe from anoxic stock solutions. The incubation temperature was $60^{\circ} \mathrm{C}$. Pure cultures were isolated by dilution series using the shake tube culture method (Widdel \& Pfennig, 1984 ) with anoxic Gelrite gellan gum (final concentration $0.3 \%$, w/v; Kelco Division of Merck) as the gelling agent and starch (final concentration $0.5 \%, \mathrm{w} / \mathrm{v}$ ) as the substrate.

Microscopy. Cells were observed with a Labophot (Nikon) and a Vanox (Olympus) phase microscope to determine purity, morphology and Gram reaction, and to make photomicrographs (Pfennig \& Wagner, 1986). Cells for electron microscopy were fixed in the medium with $1.5 \%$ (v/v) glutaraldehyde for $30 \mathrm{~min}$ on ice. After washing with Tris/EDTA buffer (20 mM Tris, $1 \mathrm{mM}$ EDTA, pH 6.8), a piece of carbon support film, about $10 \mathrm{~nm}$ thick, was floated on the surface of the sample. After attachment of the bacteria, the carbon film was washed with Tris/EDTA buffer and distilled water, picked up with 300 mesh copper grids and immediately blotted dry on filter paper. The grids were mounted on carbon conductivity tabs on stubs and, without further sputtering, observed in a Zeiss DSM982 Gemini at $1 \mathrm{kV}, 10 \mu \mathrm{m}$ aperture and $3 \mathrm{~mm}$ working distance using the in-lens detector.

Serology. Polyclonal antiserum was produced against strain
SJ95 ${ }^{\mathrm{T}}$ as described previously (Christensen et al., 1992). Antigens were characterized by Western immunoblotting of SDS-soluble whole-cell extracts. SDS-PAGE of the wholecell extracts was carried out as described by Laemmli (1970) with 12.5 and $4.5 \%(\mathrm{w} / \mathrm{v})$ polyacrylamide in the separation and stacking gels, respectively. The electrophoresis and subsequent immunoblotting were run as described previously (Christensen et al., 1992).

Growth and metabolism. Growth (in Bellco tubes) was determined as an increase in $\mathrm{OD}_{600}$. Hydrogen and carbon dioxide gases were determined with a Varian model $3300 \mathrm{GC}$ equipped with a thermal conductivity detector and a Cromopack $45 / 60$ molecular sieve $10^{\prime} \times 1 / 8^{\prime \prime}(3.0 \mathrm{~m}$ by $3.2 \mathrm{~mm}$ ) stainless steel column. The oven, injector and detector temperatures were 60,125 and $125^{\circ} \mathrm{C}$, respectively, and the carrier gases for determination of hydrogen and carbon dioxide were argon and helium, respectively.

Short-chain fatty acids and alcohols were determined by HPLC using an Aminex HPX-87 column $(300 \times 7.5 \mathrm{~mm}$;

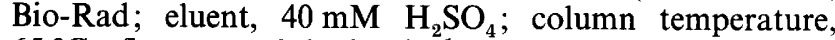
$65^{\circ} \mathrm{C}$; flow rate $0.6 \mathrm{ml} \mathrm{min}-1$ ) and a Refractive Index Detector 156 (Altex) at $35^{\circ} \mathrm{C}$. The injection volume was $100 \mu \mathrm{m}$.

Xylanase activity was determined photometrically by measuring the increase in reducing sugars released from birch wood xylan (Roth) using $p$-hydroxybenzoic acid hydrazide (PAHBAH) reagent (Lever, 1972). The standard incubation mixture contained: $1.8 \mathrm{ml} 1 \%$ birch wood xylan suspended in $50 \mathrm{mM}$ potassium phosphate buffer, $\mathrm{pH} 6.5$, and $0.2 \mathrm{ml}$ enzyme solution. Standard incubation conditions were $5 \mathrm{~h}$ at $60^{\circ} \mathrm{C}$, after which the reaction was stopped by the addition of $3 \mathrm{ml}$ PAHBAH reagent. After colour development for $5 \mathrm{~min}$ at $90-100^{\circ} \mathrm{C}, A_{410}$ was determined. In the enzyme blank, the enzyme was added after the addition of the PAHBAH reagent. Potassium phosphate buffer $(50 \mathrm{mM})$ was used for the determination of the effect of $\mathrm{pH}\left(\right.$ at $60^{\circ} \mathrm{C}$ ) and temperature (at pH 6.5) on enzyme activity. Xylanase activity was measured in a cell-free extract, intact cells and a culture filtrate of cells grown on xylan. These different fractions were obtained as follows. Samples of $20 \mathrm{ml}$ culture were centrifuged at $10000 \mathrm{~g}$ for $10 \mathrm{~min}$, and the supernatant was used as the culture filtrate. A suspension of intact cells (examined by microscopy) was made by suspending the pellet in $1 \mathrm{ml}$ growth medium without a substrate. The cell-free extract was prepared from $0.5 \mathrm{ml}$ cell suspension using ultrasonic disintegration followed by $10 \mathrm{~min}$ centrifugation at $10000 \mathrm{~g}$. The activity of glucose isomerase was assayed as described by Lee et al. (1990).

DNA analyses. Genomic DNA for determination of the $\mathrm{G}+\mathrm{C}$ content and DNA-DNA hybridization was isolated from $0 \cdot 4-1.0 \mathrm{~g}$ frozen and thawed bacterial pellets. RNase $\left(10 \mu 1 \mathrm{ml}^{-1}\right)$ was added, and the mixture was incubated for $60 \mathrm{~min}$ at $65^{\circ} \mathrm{C}$. Thereafter, $0.5 \mathrm{ml} 10 \%(\mathrm{w} / \mathrm{v}) \mathrm{SDS}$ and $50 \mu \mathrm{l}\left(20 \mathrm{mg} \mathrm{ml}^{-1}\right)$ proteinase $\mathrm{K}$ were added followed by incubation at $37^{\circ} \mathrm{C}$ for $1 \mathrm{~h}$. After mixing the solution with $1.8 \mathrm{ml} 5 \mathrm{M} \mathrm{NaCl}, 1.5 \mathrm{ml}$ hexadecyltrimethyl ammonium bromide (Murray \& Thompson, 1980) was added and the mixture was incubated at $65^{\circ} \mathrm{C}$ for $20 \mathrm{~min}$. An equal volume of chloroform: isoamylalcohol $(24: 1)$ was then added, and the mixture was centrifuged at $6000 \mathrm{~g}$ for $10 \mathrm{~min}$. The water phase was transferred to another tube and 0.6 vol. 2propanol was added. After $15 \mathrm{~min}$, the DNA was collected and transferred to $1 \mathrm{ml} 70 \%$ ethanol and centrifuged for $5 \mathrm{~min}$ at $10000 \mathrm{~g}$. The pellet was washed in $70 \%$ ethanol and 
finally dissolved in $1 \mathrm{ml} 20 \mathrm{mM}$ Tris/ $\mathrm{HCl}$ buffer containing $1.0 \mathrm{mM}$ EDTA. The $\mathrm{G}+\mathrm{C}$ content of the DNA was measured by both the thermal denaturation method (De Ley, 1970), with Escherichia coli B type VIII DNA (no. D2001 ; Sigma) as a reference, and the chemical method using HPLC to separate and quantify nucleosides (Mesbah et al., 1989). For DNA-DNA hybridization studies, DNA was first subjected to hydroxyapatite chromatography (Cashion et al., 1977); hybridization was carried out according to De Ley et al. (1970) with modifications using a Gilford System 2600 spectrophotometer equipped with a Gilford 2527-R thermoprogrammer and plotter. The DNA-DNA hybridization was carried out by M. Steffen at the DSMZ.

165 rDNA sequence determination and analysis. Genomic DNA extraction, PCR-mediated amplification of the $16 \mathrm{~S}$ rDNA, and purification of PCR products were carried out using procedures described previously (Rainey et al., 1996; Rainey \& Stackebrandt, 1993). Purified PCR products were sequenced using the Taq DyeDeoxy Terminator Cycle Sequencing kit (Applied Biosystems) as directed in the manufacturer's protocol. The Applied Biosystems 373A DNA Sequencer was used for electrophoresis of the sequence reaction products. The $16 \mathrm{~S}$ rDNA sequence was manually aligned against $P$. miotherma, Geotoga and other Thermotogales representatives. Pairwise evolutionary distances were computed using the correction of Jukes \& Cantor (1969). The least-squares distance method of De Soete (1983) was used in the construction of the phylogenetic dendrogram from distance matrices.

Nucleotide sequence accession numbers. The accession numbers of the reference strains used in the sequence comparison are as follows: Aquifex pyrophilus, M83548; Fervidobacterium islandicum, M59176; Fervidobacterium nodosum, M59177; Geotoga petraea, L10658; Geotoga subterranea, L10659; Petrotoga miotherma, L10657; Thermosipho africanus, M24022; Thermotoga maritima, M21774; and Thermotoga thermarum, ARB8587.

\section{RESULTS}

\section{Enrichment and isolation}

Bacteria with an outer sheath (toga) were first observed in enrichment cultures of a thermophilic spore-forming Desulfotomaculum $\mathrm{sp}$. This binary culture grown at $60{ }^{\circ} \mathrm{C}$ converted mono- and disaccharides to hydrogen sulfide, acetate, hydrogen and ethanol (Rosnes et al., 1991b). Efforts were made to isolate the different members of the culture; Desulfotomaculum sp. was isolated by autoclaving the culture at $121^{\circ} \mathrm{C}$ for 20 min, which killed the sheathed bacteria, but not the sporulators with extremely heat-resistant spores (Rosnes at al., 1991a). Several dilution series were carried out in a glucose-containing medium without sulfate, but the spore-forming sulfate reducers ultimately appeared in all of the dilution tubes. However, successful enrichment of the sheathed bacteria was obtained by growing the binary culture in a mineral salt medium with starch and without sulfate. The enrichment was subcultured in this medium and during three subsequent transfers, the population developed into a culture dominated by rod-shaped bacteria with a sheath-like outer structure (toga). Several of these
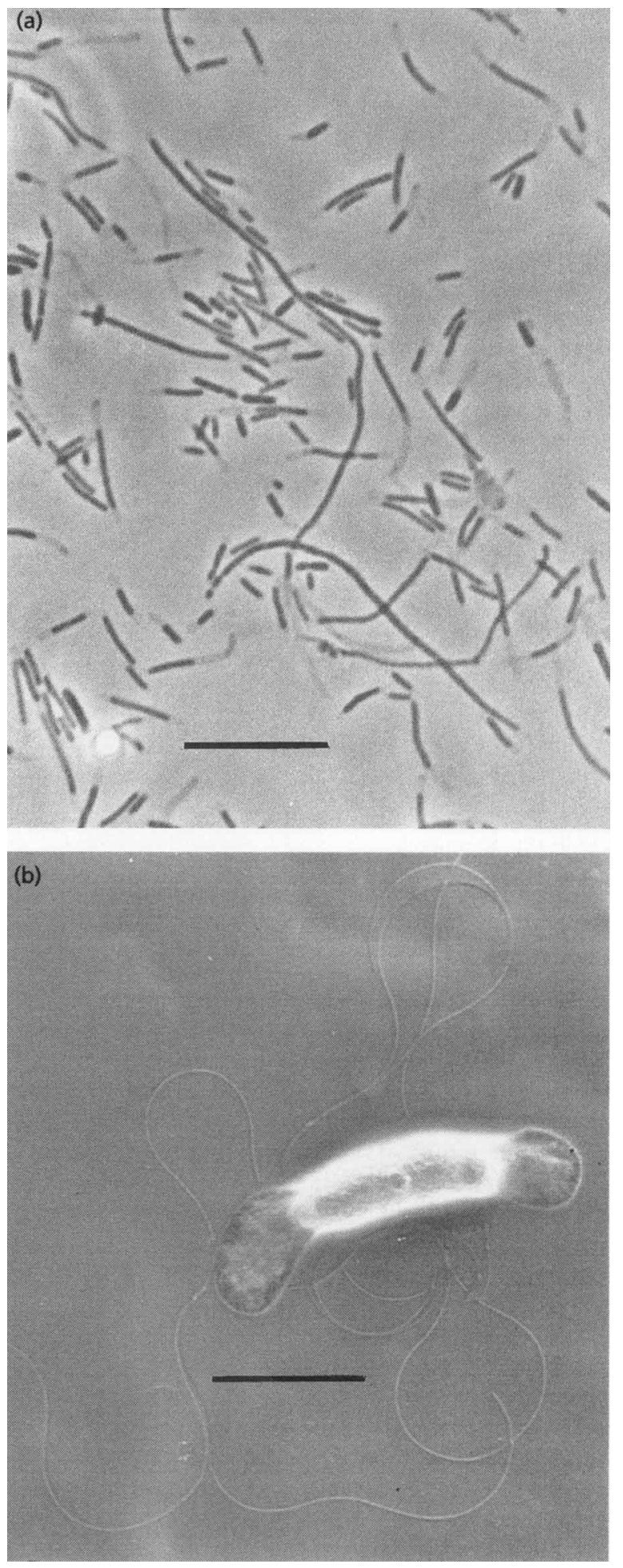

Fig. 1. Morphology of strain $S J 95^{\top}$. (a) Phase-contrast micrograph of cells. Bar, $10 \mu \mathrm{m}$. (b) Scanning electron micrograph of a cell with flagella. Bar, $2 \mu \mathrm{m}$.

bacteria were isolated in pure cultures. One of the isolates, strain $\mathrm{SJ} 95^{\mathrm{T}}$, forming circular and whitish colonies, is described in this paper. 
Table 1. Comparison of characteristics of strain $\mathrm{SJ} 95^{\top}$ and $P$. miotherma

\begin{tabular}{|c|c|c|}
\hline Characteristic & Petrotoga mobilis $\mathrm{SJ} 5^{\mathrm{T}}$ & Petrotoga miotherma \\
\hline Cell shape & Rod-shaped with toga & Rod-shaped with toga \\
\hline \multicolumn{3}{|l|}{ Cell size $(\mu \mathrm{m})$ : } \\
\hline Width & $0.5-1.5$ & $0 \cdot 6$ \\
\hline Length & $1 \cdot 0-50 \cdot 0$ & $2 \cdot 0-7 \cdot 5$ \\
\hline No. of cells per sheath & $1-24$ & $1-5$ \\
\hline Motility and flagellation & Motile, subpolar & Non-motile \\
\hline Formation of spherical bodies & - & + \\
\hline Optimum temperature $\left({ }^{\circ} \mathrm{C}\right)$ & $58-60$ & 55 \\
\hline Optimum $\mathrm{NaCl}$ requirement $\left(\mathrm{g} \mathrm{l}^{-1}\right)$ & $30-40$ & 20 \\
\hline \multicolumn{3}{|l|}{ Growth factors requirements: } \\
\hline Vitamins & + & ND \\
\hline Yeast extract & $(+)$ & + \\
\hline Reduction of $\mathrm{S}^{\circ}$ to $\mathrm{H}_{2} \mathrm{~S}$ & + & + \\
\hline DNA G $+C$ content $(\mathrm{mol} \%)$ & $31,34^{*}$ & $32,34 \cdot 25,40 \dagger$ \\
\hline \multicolumn{3}{|l|}{ Substrates utilized: } \\
\hline Xylan & + & - \\
\hline Cellulose & - & - \\
\hline Ribose & + & ND \\
\hline $\begin{array}{l}\text { Maltodextrin, glucose, lactose, } \\
\text { sucrose }\end{array}$ & + & + \\
\hline $\begin{array}{l}\text { Galactose, maltose, xylose, } \\
\text { cellobiose, fructose }\end{array}$ & + & + \\
\hline Arabinose & + & + \\
\hline
\end{tabular}

* Values obtained by the thermal denaturation and HPLC methods, respectively.

$\uparrow$ Values obtained by the thermal denaturation and HPLC methods and the HPLC value reported by Davey et al. (1993), respectively.

ND, Not determined.

\section{Morphology}

Cells of strain ST95 ${ }^{\mathrm{T}}$ are rod-shaped and vary widely in size from small ones of only about $1 \mu \mathrm{m}$ in length to those with a length of 40-50 $\mu \mathrm{m}$. The width of the cells also varied (Fig. 1a; Table 1). A surrounding sheath was clearly visible under phase microscopy. The cells frequently appeared singly, in pairs or in chains within the sheath, sometimes with more than twenty small cells per sheath or with a single small cell within a long sheath which otherwise seemed to be empty. In contrast to $P$. miotherma, strain $\mathrm{SJ} 5^{\mathrm{T}}$ did not form enlarged spherical bodies in the stationary phase (Davey et al., 1993). Gram staining was negative and no endospores were observed. However, motile cells were frequently observed and electron microscopy revealed some very long flagella $(15-16 \mu \mathrm{m})$ and subpolar flagellation (Fig. 1b). The smaller single rods moved more rapidly than the longer single cells and pairs of rods which showed a slow flexing, fishswimming motion. No twiddles, but a reversion of their swimming direction was observed.

\section{Physiology}

Strain $\mathrm{SJ}^{\mathrm{T}}$ is an obligate anaerobe that grows at temperatures between 40 and $65^{\circ} \mathrm{C}$ (optimum at $58-60^{\circ} \mathrm{C}$ ). The $\mathrm{pH}$ range for growth was $\mathrm{pH} 5 \cdot 5-8 \cdot 5$ (optimum at $\mathrm{pH} \mathrm{6.5-7.0)} \mathrm{(Table} \mathrm{1).} \mathrm{The} \mathrm{shortest}$ doubling time was about $12 \mathrm{~h}$. Growth was observed in $0.5-9.0 \%(\mathrm{w} / \mathrm{v}) \quad \mathrm{NaCl}$ and $0.1-0.8 \% \quad(\mathrm{w} / \mathrm{v})$ $\mathrm{MgSO}_{4} .7 \mathrm{H}_{2} \mathrm{O}$ and was optimal at $3-4 \% \mathrm{NaCl}$ and $0.7 \% \mathrm{MgSO}_{4} \cdot 7 \mathrm{H}_{2} \mathrm{O}$. Several vitamins, e.g. folic acid, riboflavin, pantothenic acid, cobalamin, $p$-aminobenzoate and lipoic acid $(200,500,500,10,500$ and $500 \mu \mathrm{g} \mathrm{l}^{-1}$, respectively) were required. Yeast extract $(0.02 \%, w / v)$ stimulated growth.

The growth studies were done in the presence of vitamins, $0.02 \%$ final concentration yeast extract, and $0.5 \%$ final concentration substrate. Growth was observed on: starch, xylan, maltodextrin, maltose, cellobiose, sucrose, lactose, glucose, galactose, fructose, arabinose, xylose, ribose and rhamnose as carbon and energy sources. Highest yield was obtained with ribose, maltose and dextrin. Xylanase activity, optimum at $60-65^{\circ} \mathrm{C}$ and $\mathrm{pH} 5 \cdot 5-6.0$, was detected in intact cells, in cell-free extract but not in the culture filtrate of cells grown on xylan. This indicates that the xylanase activity is located inside the toga as reported for amylases and xylanases from Thermotoga spp. (Sunna et al., 1997). Glucose isomerase was detected in cellfree extracts of cells grown on xylose.

The following substrates were tested, but not utilized: cellulose, mannose, raffinose, Casamino acids, man- 
(a)

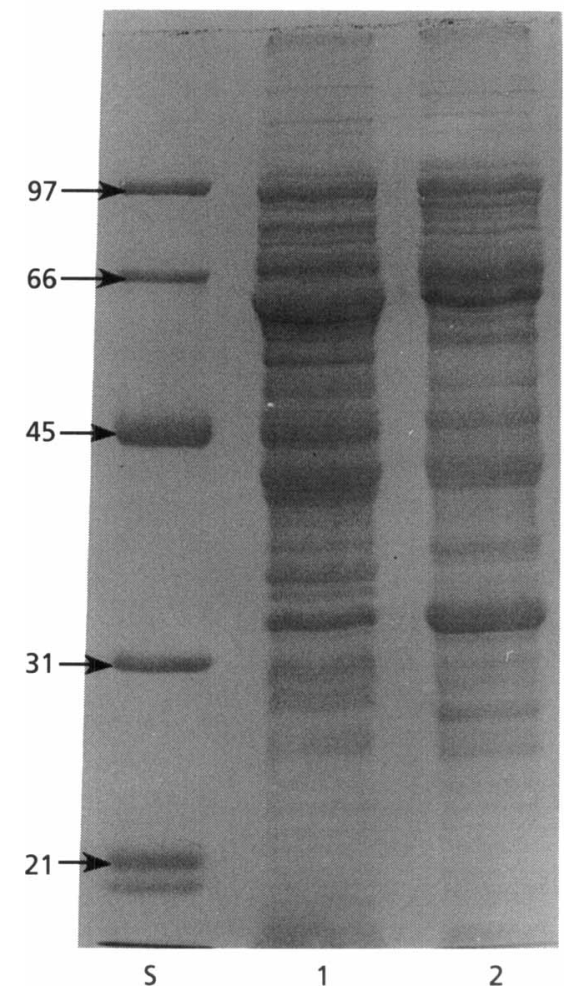

(b)

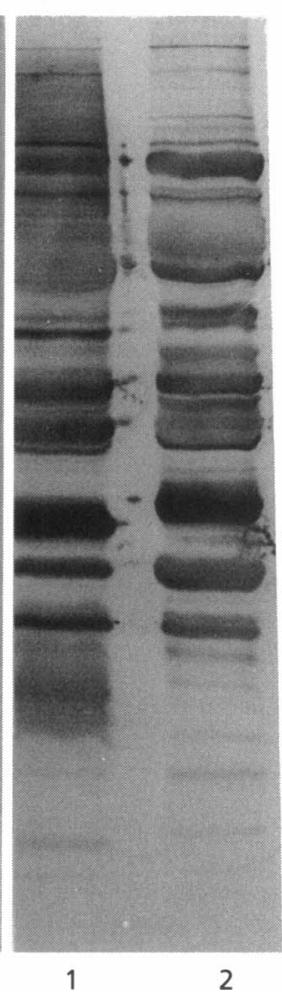

Fig. 2. Protein pattern (a) and immunoblotting with anti-SJ95 (b) after SDS-PAGE of SDS-soluble whole-cell extracts of strain SJ $95^{\top}$ (lane 1) and P. miotherma (lane 2). The positions of molecular mass standards (in $\mathrm{kDa}$ ) are indicated on the left (standards in lane S).

nitol, inositol, methanol, ethanol, propanol, butanol, formate, acetate, butyrate, valerate, caproate, malate, lactate, fumarate and pyruvate.

The fermentation products detected in cultures growing on glucose were hydrogen gas, carbon dioxide, acetate and ethanol. As observed with P. miotherma (Davey et al., 1993), no growth occurred with a headspace of $80 \%$ hydrogen and $20 \%$ carbon dioxide; this inhibition by hydrogen was eliminated by adding elemental sulfur or thiosulfate to the culture which caused production of hydrogen sulfide. Growth inhibition also occurred at low $(0.1 \%, \mathrm{v} / \mathrm{v})$ concentration of hydrogen in the headspace. Thiosulfate reduction increased cellular yields and growth rates of strain $\mathrm{SJ} 95^{\mathrm{T}}$ and $P$. miotherma (Fig. 3) similarly to that described by Ravot et al. $(1995,1996)$ for other members of the order Thermotogales.

\section{Antibiotic sensitivity}

Growth was inhibited at $10 \mu \mathrm{g} \mathrm{ml}^{-1}$ final concentration of penicillin, ampicillin, vancomycin, chloramphenicol, rifampicin and streptomycin. The inhibition was irreversible since no viable cells were obtained after washing and resuspension in the growth medium. In

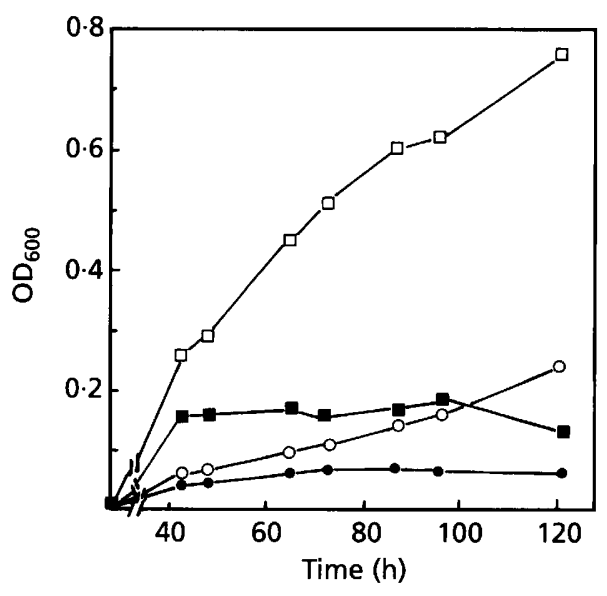

Fig. 3. Effect of thiosulfate on growth of strain $S J 95^{\top}(O, 0)$ and $P$. miotherma $(\square, \square)$. Cells were grown on maltodextrin $(0.5 \%)$ at $58{ }^{\circ} \mathrm{C}$ with $20 \mathrm{mM}$ final concentration of thiosulfate $(\square, \bigcirc)$. Controls $(\square, \boldsymbol{0})$ were grown in the absence of thiosulfate.

contrast to the results of Davey et al. (1993), streptomycin $\left(100 \mu \mathrm{g} \mathrm{ml}^{-1}\right)$ inhibited the growth of $P$. miotherma.

\section{Whole-cell protein patterns and serology}

Although P. miotherma and strain $\mathrm{SJ} 95^{\mathrm{T}}$ have proteins with the same electrophoretic behaviour in common, for example a protein with a molecular mass of about $97 \mathrm{kDa}$, strain SJ95 ${ }^{\mathrm{T}}$ contained specific protein bands (e.g. at 60,38 and $19 \mathrm{kDa}$ ) that differentiate it from $P$. miotherma (Fig. 2a). The immunoblotting (Fig. 2b) using antiserum to $\mathrm{S} J 95^{\mathrm{T}}$ demonstrated serological differences which discriminate strain $\mathrm{SJ} 95^{\mathrm{T}}$ from $P$. miotherma.

\section{DNA base composition}

The $\mathrm{G}+\mathrm{C}$ content of the DNA of strain $\mathrm{SJ} 95^{\mathrm{T}}$ was $31 \cdot 4$ and $34 \cdot 00 \pm 0 \cdot 10 \mathrm{~mol} \%(n=8)$, determined by the thermal denaturation and HPLC methods, respectively. The corresponding values found for DNA from $P$. miotherma were 32 and $34 \cdot 25 \pm 0 \cdot 16 \mathrm{~mol} \%(n=7)$. In addition, it is noteworthy that neither DNA sample contained detectable 5-methylcytidine. The sensitivity of the chemical method for detecting this modified base in the DNA was $>0.3 \%$ of the total DNA or $1.7 \%$ of the cytidine.

\section{Phylogenetic analysis}

A 16S rDNA sequence comprising $1473 \mathrm{nt}$ between positions 32 and 1534 ( $E$. coli positions) was determined for strain SJ95 ${ }^{\mathrm{T}}$. A comparison of $1179 \mathrm{nt}$ between positions 32 and 1357 (E. coli positions) of the 16S rDNA sequence of strain $\mathrm{SJ} 95^{\mathrm{T}}$ was made with eight representatives of the order Thermotogales and Aquifex pyrophilus. The resulting phylogenetic dendro- 


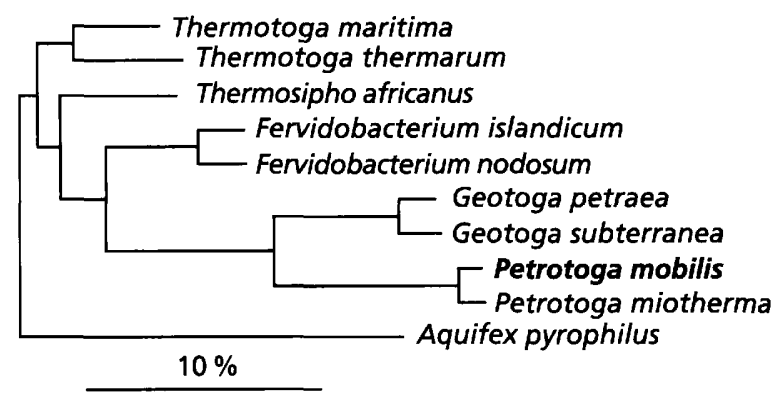

Fig. 4. Phylogenetic dendrogram based on $16 \mathrm{~S}$ rDNA sequence comparison indicating the position of Petrotoga mobilis (strain SJ95) within the radiation of the bacterial Thermotogales group. Bar, 10 nucleotide changes per 100 nucleotides.

gram (Fig. 4) shows strain SJ95 ${ }^{\mathrm{T}}$ to be closely related to the Geotoga/Petrotoga lineage within the Thermotogales. 16S rDNA similarity values between SJ95 and members of the Thermotogales are 77.9-97.9\%. The highest $16 \mathrm{~S}$ rDNA sequence similarity in the comparison of the sequences of the strains shown in Fig. 4 is to $P$. miotherma at $97.9 \%$. Direct pairwise comparison of the $16 \mathrm{~S}$ rDNA sequences of strain $\mathrm{SJ} 95^{\mathrm{T}}$ and P. miotherma showed a similarity of $97.7 \%$.

\section{DNA-DNA homology}

The DNA-DNA homology of strain SJ95 ${ }^{\mathrm{T}}$ and $P$. miotherma was examined; the hybridization value was $35.6 \%$.

\section{DISCUSSION}

Strain $\mathrm{SJ} 95^{\mathrm{T}}$ was tentatively identified as a member of the Thermotogales mainly because of its rod-shaped cells with an outer sheath-like structure and its thermophilicity. This relationship was confirmed by 16S rDNA sequence analysis which showed that strain $\mathrm{SJ} 95^{\mathrm{T}}$ is most closely related to $P$. miotherma. Furthermore, strain $\mathrm{SJ} 95^{\mathrm{T}}$ shares several phenotypic properties with this species, e.g. moderate thermophilicity, a high salt tolerance, capability of fermenting a broad spectrum of carbohydrates, and a variable cell size (Table 1).

However, strain $\mathrm{SJ} 95^{\mathrm{T}}$ is significantly different from $P$. miotherma. Firstly, strain SJ95 $5^{\mathrm{T}}$ is motile with subpolar flagellation. The cells are longer $(40-50 \mu \mathrm{m})$ than those of $P$. miotherma $(7.5 \mu \mathrm{m})$ and they do not form enlarged spherical bodies in the stationary phase. Secondly, strain $\mathrm{SJ} 95^{\mathrm{T}}$ is able to grow on xylan with toga-associated xylanase activity. Thirdly, the protein profile and the antigen pattern of SDS-soluble wholecell extracts are different in strain $\mathrm{SJ}^{\mathrm{T}}{ }^{\mathrm{T}}$ and $P$. miotherma. Fourthly, the level of $16 \mathrm{~S}$ rDNA sequence similarity of $97.7 \%$ is sufficiently low to establish a new species (Stackebrandt \& Goebel, 1994). Fifthly, the DNA base composition is slightly different according to results obtained using two different and unreliable methods, but differs by $6 \%$ according to the reported values for P. miotherma (Davey et al., 1993). Finally, the level of DNA-DNA hybridization of $35.6 \%$ between strain $\mathrm{SJ} 5^{\mathrm{T}}$ and $P$. miotherma is too low for these organisms to be considered as members of the same species. On the basis of these data, strain SJ95 ${ }^{\mathrm{T}}$ can be considered a new species of the genus Petrotoga, for which the name Petrotoga mobilis is proposed.

\section{Description of Petrotoga mobilis sp. nov.}

Petrotoga mobilis (mo'bi.lis. L. fem. adj. mobilis motile).

Rod-shaped cells with a sheath-like outer structure, Gram-negative, obligately anaerobic, heterotrophic, able to ferment a broad spectrum of carbohydrates including xylan. The cells vary in size $(0 \cdot 5-1 \cdot 0$ by $1 \cdot 0-50 \mu \mathrm{m})$ and can be single, in pairs or in chains, sometimes with more than 20 cells within the sheath. Frequently motile with subpolar flagellation. Neither endospores nor enlarged spherical bodies in stationary phase are formed. Growth occurs at $\mathrm{pH} 5 \cdot 5-8.5$, $40-65^{\circ} \mathrm{C}$ and at $\mathrm{NaCl}$ concentrations of $0 \cdot 5-9 \cdot 0 \%$ $\mathrm{NaCl}$ (optimum at 3-4\%). Several vitamins are required and yeast extract stimulates growth. The DNA $\mathrm{G}+\mathrm{C}$ content is 31 and $34 \mathrm{~mol} \%$, as determined by thermal denaturation and HPLC methods, respectively. Isolated from hot oilfield water from an oil reservoir in the North Sea. The type strain is SJ95 (= DSM $\left.10674^{\mathrm{T}}\right)$.

\section{ACKNOWLEDGEMENTS}

We are indebted to the Norwegian Research Council for financial support and to the Norwegian oil company, STATOIL, for sample collection. We thank M. Rohde at DSMZ, Braunschweig, Germany, for electron micrography. A part of this work has been carried out at the Department of Microbiology, University of Georgia, Athens, where we want to thank J. Wiegel for using his laboratory facilities and W. B. Whitman for the determination of DNA base composition.

\section{REFERENCES}

Andrews, K. T. \& Patel, B. K. C. (1996). Fervidobacterium gondwanense sp. nov., a new thermophilic anaerobic bacterium isolated from nonvolcanically heated geothermal waters of the Great Artesian Basin of Australia. Int $J$ Syst Bacteriol 46, 265-269.

Balch, W. E., Fox, G. E., Magrum, L. J., Woese, C. R. \& Wolfe, R. S. (1979). Methanogens: re-evaluation of a unique biological group. Microbiol Rev 43, 260-296.

Beeder, J., Nilsen, R. K., Rosnes, J. T., Torsvik, T. \& Lien, T. (1994). Archaeoglobus fulgidus isolated from hot North Sea oil field waters. Appl Environ Microbiol 60, 1227-1231.

Beeder, J., Torsvik, T. \& Lien, T. (1995). Thermodesulforhabdus gen. nov., sp. nov., a novel thermophilic sulfate-reducing bacterium from oil field water. Arch Microbiol 164, 331-336.

Cashion, P., Holder-Franklin, M. A., McCully, J. \& Franklin, M. (1977). A rapid method for the base ratio determination of bacterial DNA. Anal Biochem 81, 461-466.

Christensen, B., Torsvik, T. \& Lien, T. (1992). Immuno- 
magnetically captured thermophilic sulfate-reducing bacteria from North Sea oil field waters. Appl Environ Microbiol 58,1244-1248.

Davey, M. E., Wood, W. A., Key, R., Nakamura, K. \& Stahl, D. A. (1993). Isolation of three species of Geotoga and Petrotoga: two new genera, representing a new lineage in the bacterial line of descent distantly related to the 'Thermotogales'. Syst Appl Microbiol 16, 191-200.

De Ley, J. (1970). Reexamination of the association between melting point, buoyant density, and chemical base composition of deoxyribonucleic acid. $J$ Bacteriol 54, 738-754.

De Ley, J., Cattoir, H. \& Reynaterts, A. (1970). The quantitative measurement of DNA hybridization from renaturation rates. Eur J Biochem 12, 133-142.

De Soete, G. (1983). A least squares algorithm for fitting additive trees to proximity data. Psychometrika 48, 621-626.

Fardeau, M.-L., Ollivier, B., Patel, B. K. C., Magot, M., Thomas, P., Rimbault, A., Rocchiccioli, F. \& Garcia, J.-L. (1997). Thermotoga hypogea sp. nov., a xylanolytic, thermophilic bacterium from an oil-production well. Int $J$ Syst Bacteriol 47, 1013-1019.

Huber, R., Langworthy, T. A., König, H., Thomm, M., Woese, C. R., Sleytr, U. B. \& Stetter, K. O. (1986). Thermotoga maritima sp. nov. represents a new genus of unique extremely thermophilic eubacteria growing up to $90^{\circ} \mathrm{C}$. Arch Microbiol 144, 324-333.

Huber, R., Woese, C. R., Langworthy, T. A., Fricke, H. \& Stetter, K. O. (1989). Thermosipho africanus gen. nov. represents a new genus of thermophilic eubacteria within the 'Thermotogales'. Syst Appl Microbiol 12, 32-37.

Huber, R., Woese, C. R., Langworthy, T. A., Kristjansson, J. K. \& Stetter, K. O. (1990). Fervidobacterium islandicum sp. nov., a new extremely thermophilic eubacterium belonging to the 'Thermotogales'. Arch Microbiol 154, 105-111.

Jeanthon, C., Reysenbach, A. L., L'Haridon, S., Gambacorta, A., Pace, N. R., Glénat, P. \& Prieur, D. (1995). Thermotoga subterranea sp. nov., a new thermophilic bacterium isolated from a continental oil reservoir. Arch Microbiol 164, 91-97.

Jukes, T. H. \& Cantor, R. (1969). Evolution of protein molecules. In Mammalian Protein Metabolism, pp. 21-132. Edited by $\mathrm{H}$. N. Munro. New York: Academic Press.

Koch, R., Canganella, F., Hippe, H., Jahnke, K. D. \& Antranikian, G. (1997). Purification and properties of a thermostable pullulanase from a newly isolated thermophilic bacterium, Fervidobacterium pennavorans Ven5. Appl Environ Microbiol 63, 10881094.

Laemmli, U. K. (1970). Cleavage of structural proteins during the assembly of the head of bacteriophage T4. Nature 227, 680-685.

Lee, C., Bhatnagar, L., Saha, B. C., Lee, Y.-E., Takagi, M., Imanaka, T., Bagdasarian, M. \& Zeikus, J. G. (1990). Cloning and expression of the Clostridium thermosulfurogenes glucose isomerase gene in Escherichia coli and Bacillus subtilis. Appl Environ Microbiol 56, 2638-2643.

Lever, M. (1972). A new reaction for colorimetric determination of carbohydrates. Anal Biochem 47, 273-279.

Lien, T. \& Beeder, J. (1997). Desulfobacter vibrioformis sp. nov,, a sulfate reducer from a water-oil separation system. Int $J$ Syst Bacteriol 47, 1124-1128.

Mesbah, M., Premachandran, U. \& Whitman, W. B. (1989). Precise measurement of the $\mathrm{G}+\mathrm{C}$ content of deoxyribonucleic acid by high-performance liquid chromatography. Int J Syst Bacteriol 39, 159-167.
Murray, M. G. \& Thompson, W. F. (1980). Rapid isolation of high molecular weight plant DNA. Nucleic Acids Res 8, 4321-4325. Nilsen, R. K. \& Torsvik, T. (1996). Methanococcus thermolithotrophicus isolated from North Sea oil field reservoir water. $\mathrm{Appl}$ Environ Microbiol 62, 728-731.

Nilsen, R. K., Torsvik, T. \& Lien, T. (1996). Desulfotomaculum thermocisternum sp. nov., a sulfate reducer isolated from a hot North Sea oil reservoir. Int J Syst Bacteriol 46, 397-402.

Pfennig, N. \& Wagner, S. (1986). An improved method of preparing wet mounts for photo-micrographs of microorganisms. J Microbiol Methods 4, 303-306.

Rainey, F. A. \& Stackebrandt, E. (1993). 16S rDNA analysis reveals phylogenetic diversity among the polysaccharolytic clostridia. FEMS Microbiol Lett 113, 125-128.

Rainey, F. A., Ward-Rainey, N., Kroppenstedt, R. M. \& Stackebrandt, E. (1996). The genus Nocardiopsis represents a phylogenetically coherent taxon and a distinct actinomycete lineage: proposal of Nocardiopsaceae fam. nov. Int J Syst Bacteriol 46, 1088-1092.

Ravot, G., Ollivier, B., Magot, M., Patel, B. K. C., Crolet, J.-L., Fardeau, M.-L. \& Garcia, J.-L. (1995). Thiosulfate reduction, an important physiological feature shared by members of the order Thermotogales. Appl Environ Microbiol 61, 2053-2055.

Ravot, G., Ollivier, B., Patel, B. K. C., Magot, M. \& Garcia, J.-L. (1996). Emended description of Thermosipho africanus as a carbohydrate-fermenting species using thiosulfate as an electron acceptor. Int J Syst Bacteriol 46, 321-323.

Rees, G. N., Grassia, G. S., Sheehly, A. J., Dwivedi, P. P. \& Patel, B. K. C. (1995). Desulfacinum infernum gen. nov., sp. nov., a thermophilic sulfate-reducing bacterium from a petroleum reservoir. Int J Syst Bacteriol 45, 85-89.

Rosnes, J. T., Torsvik, T. \& Lien, T. (1991a). Spore-forming thermophilic sulfate-reducing bacteria isolated from North Sea oil field waters. Appl Environ Microbiol 57, 2302-2307.

Rosnes, T., Torsvik, T., Lien, T. \& Graue, A. (1991b). Degradation of glucose and production of $\mathrm{H}_{2} \mathrm{~S}$ by a consortium of thermophilic bacteria under simulated reservoir conditions. In Microbial Enhancement of Oil Recovery-Recent Advances, pp. 265-276. Edited by E. C. Donaldson. Amsterdam: Elsevier.

Stackebrandt, E. \& Goebel, B. M. (1994). Taxonomic note: a place for DNA-DNA reassociation and 16S rRNA sequence analysis in the present species definition in bacteriology. Int $J$ Syst Bacteriol 44, 846-849.

Sunna, A., Moraca, M. \& Antranikian, G. (1997). Glycosyl hydrolases from hyperthermophiles. Extremophiles 1, 2-13.

Stetter, K. O., Huber, R., Blochl, E., Kurr, M., Eden, R. D., Fielder, M., Cash, H. \& Vance, I. (1993). Hyperthermophilic Archaea are thriving in deep North Sea and Alaskan oil reservoirs. Nature 365, 743-745.

Widdel, F. \& Pfennig, N. (1984). Dissimilatory sulfate- or sulfurreducing bacteria. In Bergey's Manual of Systematic Bacteriology, vol. 1, pp. 663-679. Edited by N. R. Krieg \& J. G. Holt. Baltimore: Williams \& Wilkins.

Widdel, F., Kohringen, G. W. \& Mayer, F. (1983). Studies of dissimilatory sulfate-reducing bacteria that decompose fatty acids. III. Characterization of the filamentous gliding Desulfonema limicola gen. nov. and sp. nov. and Desulfonema magnum sp. nov. Arch Microbiol 129, 286-294.

Winker, S. \& Woese, C. R. (1991). A definition of the domains Archaea, Bacteria and Eucarya in terms of small subunit ribosomal RNA characteristics. Syst Appl Microbiol 13, 161-165. 